\title{
Tutorial Accounting Fundamentals: A New Look of British and American Accounting System
}

\author{
Nousheen Tariq Bhutta ${ }^{1 *}$, Syed Zulfiqar Ali Shah ${ }^{2}$ \\ ${ }^{1}$ Faculty of Management Sciences, International Islamic University, Islamabad, Pakistan \\ ${ }^{2}$ Higher Studies and Research, Faculty of Management Sciences, International Islamic University, Islamabad, Pakistan \\ Email: ${ }^{\prime}$ imaantariq@gmail.com, zulfiqar.shah@gmail.com
}

Received November 1, 2012; revised December 7, 2012; accepted December 15, 2012

\begin{abstract}
This paper aims to highlight the perception of graduate and undergraduate students regarding accounting fundamentals across British system and American system. The design of this paper is to derive a unique model which proves the both approaches are in same sense however, they are framed differently. Moreover, it provides a good justification of basic questions like why income and expense are treated as credit side and debit side of trading profit and loss account, respectively. Ultimately, it helps educators/instructors in influencing the perceptions of their students with regard to different accounting systems.
\end{abstract}

Keywords: Accounting Fundamentals; American Accounting; British Accounting; Students' Perceptions

\section{Introduction}

Debit and credits are merely right or left conventions used in accounting, however, many countries treat them differently like some economies follow the left way for driving and some follow right way. There is no hard and fast rule to treat them as left and right. Countries use debits and credit based on theses assumption [1].

Table 1 shows that debit and credit rules to different charts of accounts. Assets are increased by debit and decreased by credit whereas liabilities and owner's equity are increased by credit and decreased by debits. Expense is increased by debits and decreased by credits and income is increased by credit and decreased by debits.

In Pakistan, college students read financial accounting course based on British accounting system; however, university students read financial accounting course based on American accounting system. Students perceive differently to analyze the business transactions across American and British accounting system. So, in order to address this issue, this study provides an excellent understanding towards both approaches, reflecting the prime objective of this study.

One approach regarding to American accounting system is when we provide benefit is credit and when we take benefit is Debit. It satisfies the debit and credit rules for income and expenses, assets, liabilities and owner's equity [2]. The rules of debit and credit for each account are presented in Table 1, as discussed in [3].

"Corresponding author.
However, the other approach i.e. British accounting defines those things which would come into business are referred as Debit and those things which would go out from business are referred as Credit. According to this assumption it satisfies the rules for debit and credit for balance sheet items only like assets, liabilities and owner's equity, however does not apply for income statement items like incomes, expenses and net income/net loss. As income comes into business it must be debit and expenses are costs go out from business it must be credit. But why they both have their normal balance adversely related to the above assumption. Moreover, why they both treated oppositely in trading profit and loss account regarding the aforementioned logic, highlights the second theme of this study [4]. There is no study till date that investigates this gap in literature. So the second specialty of our study is to gain the attention of academicians and practitioners towards this gap and provide a new look (simultaneous) approach.

Table 1. Debits and credits rule.

\begin{tabular}{ccc}
\hline Account Type & Increase is recorded by & Decrease is recorded by \\
\hline Assets & Debit & Credit \\
Expense & Debit & Credit \\
Revenue & Credit & Debit \\
Liability & Credit & Debit \\
Owner's Equity & Credit & Debit \\
\hline
\end{tabular}




\section{Research Questions}

Why income and expenses treat as credit and debit respectively?

\section{Theoretical Framework}

Assets are economic resources that will provide benefit in future whereas liabilities are debt obligation which we have to meet in future. Generally, assets have debit balance and liabilities have credit balance [2].

As per accounting all debits must be equal to all credits. Therefore, we can say that assets must be equal to liabilities, shown in Equation (1)

$$
\text { Assets }=\text { Liabilities }
$$

Assets have debit normal balance; however liabilities have credit normal balance. We assume that Debits are $(+)$ and Credits are (-), so we can assign symbol to assets as $(+)$ and liabilities $(-)$ respectively, shown in Table 2.

Moreover, liabilities can be internal and external as well. The liabilities generated due to external financing (like account payables) are referred to liabilities. The liabilities are of internal nature referred to Owner's Equity (William, et al., 2002). Thus, the breakup of liabilities of Equation (1) is shown in Equation (2)

$$
\text { Assets = Liabilities + Owner's Equity }
$$

As owner's equity is a part of liabilities, it must have same credit and negative nature, as shown in Table 3. We used (+) for assets and (-) for liabilities and owner' equity.

The components of each variable of Equation (2) have been presented in ensuing paragraphs.

There are two types of assets, based on nature [5].

Tangible: Those have physical existence like Plant \& Machinery, Land and furniture.

Intangible: Those don't have physical existence like Goodwill, Patents and Copyright.

Based on liquidity and duration, assets can be divided into two classes.

Current Assets: Those assets which are easily convertible into cash. They are converted to cash within a year.

Table 2. Balance sheet equation.

\begin{tabular}{cc}
\hline Assets & Liabilities \\
\hline Debits & Credits \\
+ & - \\
\hline
\end{tabular}

Table 3. Balance sheet equation.

\begin{tabular}{ccc}
\hline Assets & Liabilities & Owner' Equity \\
\hline Debits & Credits & Credits \\
+ & - & - \\
\hline
\end{tabular}

We can refer them as short term assets.

Fixed Assets: Those assets which are not easily converted into cash, referred as long-term assets, particularly 3 - 5 years while concerning the other side of balance sheet equation, liabilities are of two types.

Current Liabilities: Those we retire within a year. These are short term liabilities.

Long term liabilities: Those we retire within 3 - 5 years, called long term liabilities.

The other element of balance sheet equation is Owner's Equity. The components of owner's equity have been discussed in following points:

\subsection{Direct/Single Effect Components}

- Investment: It is additional capital provided by owner or external financer. As it is injection of capital in business, it will increase the capital account. Thus, it is of positive nature and we assign it $(+)$.

- Drawings: Owners withdraw goods or cash for his business use. It reduces the capital account. Thus, it is of negative nature and we assign it $(-)$.

- Dividend: It is distribution of profit to shareholders. It reduces the capital account. Thus, it is of negative nature and we assign it $(-)$.

\subsection{Indirect/Dual Effect Components}

- Income/Sales: Value of goods and services charged from customer. It increases the business revenue and the capital amount. Thus, it is of positive nature and we assign it $(+)$.

- Expenses: It is cost incurred for generating the revenue. It diminishes the business income and the capital amount. Thus, it is of negative nature and we assign it $(-)$.

- Net Income: It is overall profit of business transacttions. It will enhance the business revenue and the capital amount. Thus, it is of positive nature and we assign it $(+)$.

The components of Owner's Equity are shown in Table 4. We assigned (+) and ( $(-)$ sign to above mentioned components based on their normal nature. Like $(+)$ is used for investment, sales/revenue and net income; however, $(-)$ is used for drawings, dividend and expenses.

As it is part of Owner Equity, We placed owner's equity as additional left column to Table 5. We used (-) for owner's equity based on its credit nature.

In next step the sign of components changed due to (-) sign of owner equity, as shown in Table 6. The new sign of investment, sales/revenue and net income is $(-)$ and drawings, dividend and expenses is $(+)$. Then we used debit for $(+)$ and credit for $(-)$. Therefore, drawings, dividend and expenses have debit nature and investment, sales/revenue and net income have credit nature. 
Table 4. Components of owner equity.

\begin{tabular}{cccccc}
\hline \multicolumn{3}{c}{ Direct/Single Effect Components } & \multicolumn{3}{c}{ Indirect/Dual Effect Components } \\
\hline \multirow{2}{*}{ Investment } & Drawings & Dividend & Revenue/Sales & Expenses & Net Income \\
Debits & Credits & Credits & Debits & Credits & Debits \\
+ & - & - & + & - & + \\
\hline
\end{tabular}

Table 5. Old position of components of owner equity.

\begin{tabular}{ccccccc}
\hline \multirow{2}{*}{ Owner's Equity } & \multicolumn{3}{c}{ Direct/Single Effect Components } & \multicolumn{3}{c}{ Indirect/Dual Effect Components } \\
\cline { 2 - 7 } & Investment & Drawings & Dividend & Revenue/Sales & Expenses & Net Income \\
\hline Credit & Debits & Credits & Credits & Debits & Credits & Debits \\
- & + & - & - & + & - & + \\
\hline
\end{tabular}

Table 6. New position of owner equity components.

\begin{tabular}{|c|c|c|c|c|c|c|}
\hline \multirow{2}{*}{ Owner's Equity } & \multicolumn{3}{|c|}{ Direct/Single Effect Components } & \multicolumn{3}{|c|}{ Indirect/Dual Effect Components } \\
\hline & Investment & Drawings & Dividend & Revenue/Sales & Expenses & Net income \\
\hline Credit & Debits & Credits & Credits & Debits & Credits & Debits \\
\hline \multirow[t]{3}{*}{-} & + & - & - & + & - & + \\
\hline & \multicolumn{4}{|c|}{ New Position } & & \\
\hline & Investment & Drawings & Dividend & Revenue/Sales & Expenses & Net Income \\
\hline- & - & + & + & - & + & - \\
\hline Credit & Credit & Debit & Debit & Credit & Debit & Credit \\
\hline
\end{tabular}

On the basis of above analysis, we derived the basic justification for why income and expenses are credit and debit normal balance respectively. Thus, income and expenses are shown on credit side and debit side of trading profit and loss account respectively.

\section{Conclusion and Practical Implication}

This paper highlights the accounting principles across British accounting and American accounting systems. Students perceive differently regarding accounting fundamentals based on these two approaches. It derives a unique model which confirmed the both approaches are same however, they frames differently. Furthermore, it provides a good validation of basic questions like why income and expense are treated as credit side and debit side of trading profit and loss account, respectively. The practical implication of this paper is to help instructors to mould the students' perceptions regarding American and British accounting systems. This study provides a milestone for future research in order to eliminates the confu- sion in accounting fundamentals regarding to thoughts of different school.

\section{REFERENCES}

[1] J. L. Smith, R. M. Keith and W. L. Stephens, "Accounting Principles," McGraw-Hill, Irwin, 1993.

[2] J. R. William, S. F. Haka and M. S. Bettner, "Financial and Managerial Accounting: The Basis for Business Decisions," McGraw-Hill, Irwin, 2002.

[3] S. Z. A. Shah, S. A. Butt and Y. B. Tariq, "Use or Abuse of Creative Accounting Techniques," International Journal of Trade, Economics and Finance, Vol. 2, No. 6, 2011, pp. 531-536.

[4] S. A. Zeff, "Some Obstacles to Global financial Reporting Comparability and Convergence at a High Level of Quality," The British Accounting Review, Vol. 39, No. 4, 2007, pp. 290-302. doi:10.1016/j.bar.2007.08.001

[5] L. P. Neelay and F. J. Imke, "Accounting Principles \& Practices," South-Western Publishing Co., Cincinnati 1997. 